\title{
Chest Physiotherapy on Pulmonary Functions 4 Children with Cystic Fibrosis: Systematic Review of Randomized Controlled Trials
}

\author{
REEM M. ALMARAKBY, M.Sc.; EMAN I. ELHADIDY, Ph.D. and MAYA G. ALY, Ph.D. \\ The Department of Pediatric Physical Therapy, Faculty of Physical Therapy, Cairo University
}

\begin{abstract}
Background: Pulmonary disease is the main cause of morbidity and mortality in cystic fibrosis $(\mathrm{CF})$. Children with $\mathrm{CF}$ usually received chest physiotherapy as a part of their management.

Aim of Study: To systematically review the effect of chest physiotherapy on pulmonary functions in children with $\mathrm{CF}$.

Patients and Methods: Articles were identified through literature search using PubMed (MEDLINE), physiotherapy evidence database (PEDro) and Cochrane database from 2000 up to February 2019. Studies were included if they were randomized trials focused on chest physiotherapy in children with CF. Data from included studies was extracted and its methodological quality was assessed using PEDro scale. The modified Sackett scale was used to assess level of evidence of each intervention.

Results: Seven trials were identified with fair to good methodological quality. Studies were heterogeneous in regards to intervention techniques; findings were qualitatively analyzed. This review found moderate evidence about the effectiveness of postural drainage (PD), autogenic drainage(AD), non-invasive ventilation and independent active cycle of breathing technique(ACBT); limited evidence for the effectiveness of modified PD, Positive Expiratory Pressure (PEP) and therapist-assisted ACBT. Moderate evidence was found that Hayek oscillator or chest physiotherapy during anaesthesia preoperatively is ineffective in improving pulmonary functions in children with $\mathrm{CF}$.
\end{abstract}

Conclusion: The present evidence supports the use of different chest physiotherapy interventions for improving pulmonary functions in children with $\mathrm{CF}$.

Key Words: Children - Cystic fibrosis - Physiotherapy Pulmonary functions - Systematic Review.

\section{Introduction}

CYSTIC fibrosis (CF) is a genetic disorder caused by defect in the Cystic Fibrosis transmembrane conductance regulator gene (CFTR) resulting in

Correspondence to: Dr. Reem M. Almarakby, The Department of Pediatric Physical Therapy, Faculty of Physical Therapy, Cairo University excess mucous production in the lungs, pancreas, liver, and reproductive organs [1]. Children with $\mathrm{CF}$ frequently have lung infections and impaired pulmonary functions [2]. Children tend to be symptomatic at times of infection; the increased mucus production causes a persistent cough, bronchitis, or pneumonia because of the difficulty in clearing secretions [3]

Chest physiotherapy (CPT) plays an important role in the treatment of children with $\mathrm{CF}$ in order to remove airway secretions and improves ventilation; it includes many methods as the conventional techniques of postural drainage, vibration and shaking, percussion and directed coughing in addition to other alternatives as the autogenic drainage (AD), active cycle of breathing techniques (ACBT), positive expiratory pressure (PEP) and forced expiration technique (FET) [4]

Although different methods are currently used, there is limited evidence supporting its effectiveness in the management of children with CF [5]. This systematic review aimed to verify the effect of CPT interventions on pulmonary functions in children with cystic fibrosis.

\section{Patients and Methods}

\section{Search strategy:}

This study was based on the recommendations of the Preferred Reporting Items for Systematic Reviews and Meta-Analyses (PRISMA) statement [6].

Eligibility criteria were defined as the following: (1): Participants: Children with CF aged From 1 month To 18 years. (2): Interventions: The study group received any type of CPT as postural drainage (PD), percussion, vibration, ACBT, PEP and FET. (3): Comparisons: Control of standard care or 
comparisons of different CPT techniques or the same CPT technique applied at different times. (4): Outcomes: Pulmonary functions as forced vital capacity (FVC) and forced expiratory volume in one second (FEV1). (5): Study design: Randomized controlled trials (RCTs).

Electronic search was done From November 2017 to February 2019, in the Cochrane Central Register of Controlled Trials, Physiotherapy Evidence Database (PEDro), PubMed (MEDLINE) databases using the following keywords: "Cystic fibrosis" AND "Physiotherapy" OR "Physical therapy intervention" OR "Airway clearance" OR "Postural drainage" OR "Autogenic drainage" OR "Active cycle of breathing" OR "Positive expiratory pressure" OR "Forced expiration" OR "Pulmonary functions".

Search was limited to RCTs only which published from 2000 to February 2019, articles were excluded if they were not of RCT study design; the participants were adults aged over 18 years; or the article was not available in English translation. Unpublished articles were not included in the review. Two authors independently evaluated each title and abstract identified in the search against the eligibility criteria. The full text was obtained for complete analysis.

\section{Data extraction:}

Data were extracted from the included studies by one reviewer and cross-checked by a second reviewer. Data extraction form [7] included authors and year of publication, participant's characteristics, intervention and outcomes measures.

\section{Quality assessment:}

The PEDro scale [8] was applied by two authors independently to assess trial quality and any disagreements were resolved by the third author.

\section{Data analysis:}

For rating methodological quality, the following classification was used: PEDro score $<4$ indicated poor quality; 4-5 fair quality; 6-8 good quality and 9-10 excellent quality [9]. The modified Sackett scale [10] was used to assess the level of evidence:

- Level 1 a (Strong)=Well-designed meta-an- alysis, or 2 or more 'high' quality RCTs (PEDro Scale scores >_6) that show similar findings.

- Level 1b (Moderate)=One RCT of 'high' quality (PEDro Scale score ?_6).

- Level 2a (Limited)=At least one 'fair' quality RCT (PEDro Scale score=4-5).
- Level $2 b$ (Limited)=At least one well-designed non-experimental study: Non-RCT; quasiexperimental studies; cohort studies with multiple baselines; single subject series with multiple baselines.

- Level 3 (Consensus)=Agreement by an expert panel, a group of professionals in the field or a number of pre-post design studies with similar results.

- Level 4 (Conflicting) $=$ Conflicting evidence of two or more equally designed studies.

- Level 5 (No evidence)=No well-designed studies: "Poor" quality RCTs with PEDro scores < 3 ; only case studies/case descriptions, or cohort studies/single subject series with no multiple baselines).

\section{Results}

\section{Search results:}

The search identified 617 trials till February 2019. After screening titles and abstracts and removing duplicates; 7 studies [11-17] were included in this review. Search results are presented according to the PRISMA flow chart [6] in Fig. (1).

\section{Characteristics of the included studies:}

All included studies are RCTs; four of them $[12,14,15,17]$ of crossover design. Summary of the included studies is presented in Table (1). The clinical heterogeneity between the included trials did not allow the quantitative analysis of data provided by these studies.

\section{Qualitative analysis:}

\section{Participants:}

The sample size ranged from 10 to 40 . There were a total of 152 children participating across the seven RCTs, diagnosed with CF, including both genders and ages were under 18 years old, only one trail [11] included infants from 1 to 4 months of age. Two studies $[15,17]$ included children with an acute respiratory exacerbation and one study [16] included children who required elective surgery. Disease severity reported in four studies based on pulmonary function testing (FEV1) [12$14,17]$; three studies $[11,15,16]$ used sweat chloride levels or genotype.

\section{Interventions:}

The study versus the control groups in three of the included RCTs received modified versus standard PD chest physiotherapy [11], chest physiotherapy with flutter device versus PEP [13] and CPT treatment under anesthesia before surgical proce- 
dure versus following anesthesia and intubation [16].

The other four included trials of two-period crossover design; each trial used a randomized $2 \times 2$, two-sequences of treatments $(\mathrm{A} / \mathrm{B}, \mathrm{B} / \mathrm{A})$; treadmill walk with/without noninvasive ventilation (NIV) [12], AD/PD with percussion [14], highfrequency oscillation jacket/ACBT [15], therapistassisted ACBT/independent ACBT [17].

Many studies [11-14] investigated CPT in outpatient clinic or home-based, in three studies [1517] participants received chest physiotherapy in hospital. The chest physiotherapy sessions lasted from 15 to 30 minutes repeated 2 times per day.

\section{Outcome measures:}

Pulmonary functions were assessed in all included studies [11-17], pulmonary function testing was performed using spirometer, the most commonly used measures were FVC, FEV1, tidal volume (Vt), minute ventilation (MV) and mean expiratory flow (MEF). Outcomes were measured at 3 months intervals throughout long-term trials $[11,13,14]$ of 1 and 5 years.

Quality of the included studies and the level of evidence:

The methodological quality of included studies is presented in Table (2). The quality of studies ranged from good (4 studies [12,14-16]) to fair (3 studies $[11,13,17])$; with a mean PEDro score of 6.14 out of 7 (range 4 to 8 ). The seven included studies had similar groups at baseline, analyzed the between-group difference. Four studies [12,1416] carried out an intention-to-treat analysis. Four studies [12,14-16] reported $<15 \%$ loss to follow-up. Three studies $[11,13,17]$ did not conceal the allocation. The studies [11,13-16] had blinded assessors while none of the studies blinded participants or therapists.

\section{Evidence of Chest physical therapy interventions:}

The results of the 7 included trials [11-17] which investigated effects of different CPT interventions for children with CF summarized in Table (3), the CPT included the following:

1- Postural Drainage (PD):One good quality (PEDro score=8) RCT [14] gives moderate evidence (level 1b) about the effectiveness of PD physiotherapy technique with percussion in improving pulmonary functions in children with CF.

2- Modified Postural Drainage (MPD): One fair quality (PEDro score=4) RCT [11] gives limited evidence (level 2a) about the effectiveness of
MPD physiotherapy technique (without head tilting) more than standard PD chest physiotherapy in decreasing respiratory complications in infants with $\mathrm{CF}$.

3- Autogenic Drainage: One good quality (PEDro score $=8)$ RCT [14] gives moderate evidence (level 1b) about the effectiveness of AD physiotherapy technique in improving pulmonary functions in children with $\mathrm{CF}$.

4- Noninvasive Ventilation (NIV): One good quality (PEDro score=7) RCT [12] gives moderate evidence (level 1b) about the effectiveness of NIV, when used during treadmill walking test, in optimizing ventilation and increasing functional capacity in children with CF.

5- Positive Expiratory Pressure (PEP): One fair quality (PEDro score=5) RCT [13] gives limited evidence (level 2a) about the effectiveness of PEP chest physiotherapy in maintaining pulmonary functions in children with $\mathrm{CF}$ and that oscillating PEP (flutter) not as effective as PEP technique.

6- Independent Active Cycle of Breathing Technique $(A C B T)$ : One good quality (PEDro score $=8$ ) RCT [15] gives moderate evidence (level 1b) about the effectiveness of ACBT in improving pulmonary functions in children with $\mathrm{CF}$. Another fair quality (PEDro score=4) RCT [17] gives limited evidence (level $2 \mathrm{a}$ ) about the effectiveness independent ACBT in maintaining pulmonary functions in children with $\mathrm{CF}$.

7- Therapist-assisted Active Cycle of Breathing Technique (ACBT): One fair quality (PEDro score=4) RCT [17] gives limited evidence (level 2a) about the effectiveness of therapist-assisted ACBT in maintaining pulmonary functions in children with $\mathrm{CF}$, and about its carry-over effect in reduction of airways obstruction.

8- High-frequency external chest compression (HFCC): One good quality (PEDro score $=8$ ) RCT [15] gives moderate evidence (level 1b) that HFCC technique by Hayek Cuirass (oscillation jacket) is not effective for improving pulmonary functions or for airway clearance for children with $\mathrm{CF}$ when compared with ACBT.

9- Chest physiotherapy during anesthesia: One good quality (PEDro score=7) RCT [16] gives moderate evidence (level 1b) that CPT (modified postural drainage (without head-down tipping), saline instillation, manual lung hyperinflation with expiratory chest wall vibrations and tracheal tube suction) when applied during anesthesia preoperatively is ineffective in improving pulmonary functions in children with $\mathrm{CF}$. 
Criteria of PED ro Scale in : $1=$ Eligibility specified (Not included in total score); $2=$ Random allocation; $3=$ Concealed allocation; $4=$ Prognostic similarity at baseline; $5=$ Subject blinding; $6=$ Therapist blinding; $7=$ Assessor blinding; $8=85 \%$ follow-up of at least 1 key outcome; $9=$ Treatment and control subjects received treatment as allocated; $10=$ Between group statistical comparison for at least 1 key outcome; and 11=Point estimates and measures of variability provided for at least $1 \mathrm{key}$ outcome. Scoring: $\mathrm{N}=\mathrm{No}$ (absent/unclear) $=0, \mathrm{Y}=$ Yes (present) $=1$.

Talbe (1): Summary of the included studies' characteristics.

\begin{tabular}{|c|c|c|c|}
\hline Author (Year) & Participants & Intervention & Outcome measurement \\
\hline $\begin{array}{l}\text { Button et al., } \\
\text { (2003) [11] }\end{array}$ & $\begin{array}{l}\text { - } \mathrm{N}=20 \text { (gender not } \\
\text { stated) } \\
\text { - Age (range): } 1-4 \\
\text { months }\end{array}$ & $\begin{array}{l}\text { - SPT group: } 4 \text { positions: supine horizontal, prone } \\
30^{\circ} \text { head-down tilt, left \& right-side down } 30^{\circ} \\
\text { head-down tilt. } \\
\text { - MPT group: Modified } 4 \text { positions by adding a } 30^{\circ} \\
\text { head-up tilt: supine } 30^{\circ} \text { head-up, prone horizontal, } \\
\text { left \& right side down horizontal. +encourage other } \\
\text { respiratory and physical activities for mature chil- } \\
\text { dren } \\
\text { - } 1 \text { to } 3 \text { sessions/day according to symptoms }\end{array}$ & $\begin{array}{l}\text { - Pulmonary functions, FEV } 1=\text { pul- } \\
\text { monary function testing } \\
\text { - Follow-up=Baseline \& at } 3 \\
\text { months intervals throughout the } \\
5 \text { years }\end{array}$ \\
\hline $\begin{array}{l}\text { Lima et al., } \\
\text { (2014) [12] }\end{array}$ & $\begin{array}{l}\text { - } \mathrm{N}=13 \text { ( } 8 \text { boys, } 5 \\
\text { girls) } \\
\text { - Age (range) }=7-16 \\
\text { years } \\
\text { - FEV } 1<80 \% \text { of pre- } \\
\text { dicted }\end{array}$ & $\begin{array}{l}\text { - } 2 \text { sequences ( } 7 \text { patients started the test without } \\
\text { NIV then with NIV \& } 6 \text { patients did reverse order) } \\
\text { separated by } 24 \text { to } 48 \text { hours interval between tests } \\
\text { - Intervention: NIV on a BiLEVEL mode for } 30 \text { min } \\
\& \text { patients performed TWT with the device in the } \\
\text { last } 6 \text { minutes }\end{array}$ & $\begin{array}{l}\text { - Pulmonary functions, FEV1, Vt, } \\
\text { MV= Spirometry } \\
\text { - Follow-up: Before and after each } \\
\text { test. }\end{array}$ \\
\hline $\begin{array}{l}\text { Mcllwaine et al., } \\
\text { (2001) [1 3] }\end{array}$ & $\begin{array}{l}\text { - } \mathrm{N}=40(24 \text { boys, } 16 \\
\text { girls) } \\
\text { - Age (range) }=717 \mathrm{y} \\
\text { - FVC1=47\% to } \\
\quad 107 \% \text { predicted }\end{array}$ & $\begin{array}{l}\text { - CG: CPT with PEP } \\
\text { - SG: CPT with flutter device } \\
\text { - } 15 \text { to } 20 \text { minutes/session } x 2 / \text { day } \\
\text { - } 1 \text { year study }\end{array}$ & $\begin{array}{l}\text { - Pulmonary functions }=\text { FEV } 1 \text {, } \\
\text { FVC, FEF25-75 } \\
\text { - Follow-up: Baseline and at } 3 \\
\text { month intervals throughout } 1 \text { year } \\
\text { study. }\end{array}$ \\
\hline $\begin{array}{l}\text { Mcllwaine et al., } \\
\text { (2010) [14] }\end{array}$ & $\begin{array}{l}-\mathrm{N}=36(18 \text { boys }, 18 \\
\text { girls) } \\
\text { - Age (range })=12-18 \mathrm{y}\end{array}$ & $\begin{array}{l}-2 \text { groups } \\
\text { PD group: PD with percussion (5-6 positions) } \\
\text { AD group: AD for } 30 \mathrm{~min}(5-6 \text { positions }) \text { x } 2 / \text { day for } \\
1 \text { year each intervention. }\end{array}$ & $\begin{array}{l}\text { - Pulmonary functions }=\text { FEV } 1 \text {, } \\
\text { FVC, FEF25-75 } \\
\text { - Follow-up: Baseline and at } 3 \\
\text { month intervals throughout } 1 \text { year } \\
\text { study. }\end{array}$ \\
\hline $\begin{array}{l}\text { Phillips et al., } \\
\text { (2004) [15] }\end{array}$ & $\begin{array}{l}-\mathrm{N}=10(7 \text { boys, } 3 \\
\text { girls) } \\
\text { - Age (range) }=9-16 y\end{array}$ & $\begin{array}{l}\text { - } 2 \text { sequences }(\mathrm{AB} / \mathrm{BA}) \text { in } 2 \text { days } \\
\text { - Treatment } \mathrm{A}=\text { Supervised use of Hayek Oscillator } \\
1000 \text { (high -frequency oscillation jacket) on secre- } \\
\text { tion mode: } 2 \text {-phase cycle consisted of four } 2 \text {-phase } \\
\text { cycles, } 600 \text { oscillations/minute for } 3 \text { min, followed } \\
\text { by } 60 \text { oscillations/ minute for } 2 \text { min. } \\
\text { - Treatment } B=\text { Supervision of self-treatment ACBT } \\
\text { incorporating relaxed breathing control, } 3-4 \text { tho- } \\
\text { racic expansion exercises + forced expiration } \\
\text { technique. } \\
\text { - Each treatment }=20 \mathrm{~min} \times 2 / \text { day at same time of } \\
\text { day. }\end{array}$ & $\begin{array}{l}\text { - Pulmonary functions (FEV1, } \\
\text { FVC)= spirometer } \\
\text { - Follow-up: Immediately before, } \\
\text { immediately following and } 10 \\
\text { min after end of treatment. }\end{array}$ \\
\hline $\begin{array}{l}\text { Tannenbaum et } \\
\text { al., (2007) [16] }\end{array}$ & $\begin{array}{l}-\mathrm{N}=18 \text { ( } 8 \text { boys, } 10 \\
\text { girls) } \\
\text { - Age (range) }=2.8-15 \\
\text { years } \\
\text { - Required elective } \\
\text { surgery }\end{array}$ & $\begin{array}{l}\text { CPT=Modified PD (without head-down tipping) + } \\
\text { saline instillation + manual lung hyperinflation } \\
\text { with expiratory chest wall vibrations and tracheal } \\
\text { tube suction. } \\
\text { - CG: CPT following anesthesia and intubation } \\
\text { - SG: CPT treatment under anesthesia (before the } \\
\text { surgical procedure). }\end{array}$ & $\begin{array}{l}\text { - Pulmonary functions (FEV1)= } \\
\text { Standard spirometer } \\
\text { - Follow-up=24 hour before \& after } \\
\text { surgery }\end{array}$ \\
\hline $\begin{array}{l}\text { Williams et al., } \\
\text { (2001) [17] }\end{array}$ & $\begin{array}{l}\text { - } \mathrm{N}=15 \text { ( } 9 \text { boys, } 6 \\
\text { girls) } \\
\text { - Age (range) }=12-18 \\
\text { years } \\
\text { - Acute respiratory in- } \\
\text { fection }\end{array}$ & $\begin{array}{l}\text { - } 2 \text { sequences (AB/BA) with } 24 \text { hour washout period: } \\
\text { - A: Therapist-assisted ACBT: Physiotherapist pro- } \\
\text { vided manual facilitation during thoracic expansion } \\
\text { exercises and huffing. } \\
\text { - B: Independent ACBT: the patient performed ACBT } \\
\text { under supervision and verbal guidance of physio- } \\
\text { therapist. } \\
\text { - Both groups: 20min standardized ACBT (breathing } \\
\text { control, thoracic expansion exercises, forced expi- } \\
\text { rations). }\end{array}$ & $\begin{array}{l}\text { - Pulmonary functions=Tests (FVC, } \\
\text { FEV1, PEF, FEF, TLC, ITGV, } \\
\text { RV). } \\
\text { - Follow-up=Baseline \& after each } \\
\text { treatment period \& discharge day }\end{array}$ \\
\hline \multicolumn{2}{|c|}{$\begin{array}{ll}\text { ACBT }: \text { Active cycle of breathing techniques. } \\
\text { AB }: \text { Group A/group B \& BA, Group B/Group A. } \\
\text { AD }: \text { Autogenic drainage. PD: Postural drainage. } \\
\text { CF } & \text { Cystic fibrosis. } \\
\text { CG } & \text { Control group. } \\
\text { Crs } & \text { Respiratory system compliance. } \\
\text { FEF } & \text { Forced expiratory flow. }\end{array}$} & $\begin{array}{ll}\text { FEF25-75: } & \begin{array}{l}\text { Forced expiratory flow between } 25 \% \text { and } 75 \% \\
\text { of vital capacity. }\end{array} \\
\text { FEV1 } & \text { Forced expiratory volume in one second. } \\
\text { FVC } & \text { Forced vital capacity. } \\
\text { ITGV } & \text { : Intra thoracic gas volume. } \\
\text { MPT } & \text { Modified physiotherapy. } \\
\text { NIV } & \text { : Noninvasive ventilation. } \\
\text { PEF } & \text { : Peak expiratory flow. }\end{array}$ & $\begin{array}{l}\text { PEP : Positive expiratory pressure. } \\
\text { PIP : Peak inspiratory pressure. } \\
\text { Rrs : Respiratory system resistance. } \\
\text { RV : Residual volume. } \\
\text { SG : Study Group. } \\
\text { SPT : Standard physiotherapy. } \\
\text { TLC: Total lung capacity. } \\
\text { CPT : Chest Physiotherapy. }\end{array}$ \\
\hline
\end{tabular}


Table (2): Methodology assessment of included studies according to PEDro scale.

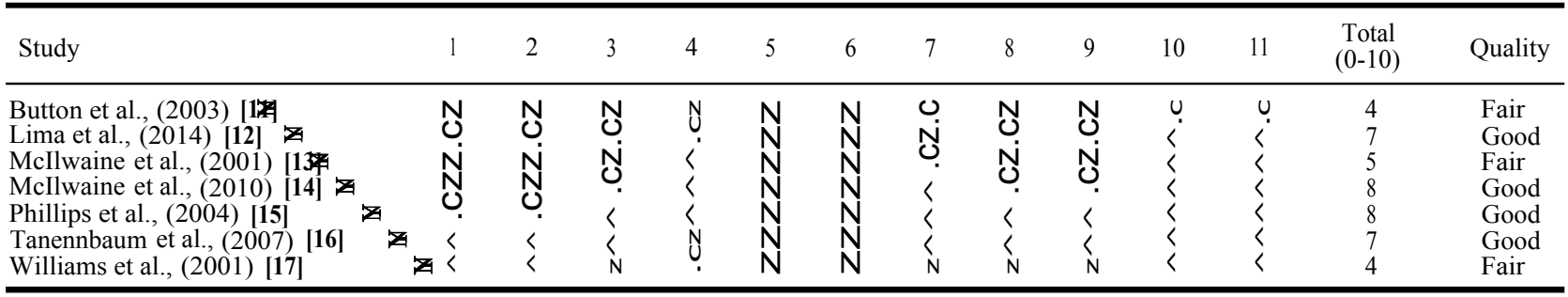

* These criteria is counted for the total PEDro score.

Table (3): Summary of results of the included studies.

\begin{tabular}{|c|c|c|c|c|}
\hline $\begin{array}{l}\text { Author } \\
\text { (Year) }\end{array}$ & $\begin{array}{c}\text { Study } \\
\text { Quality }\end{array}$ & Intervention & Main results & Authors' conclusion \\
\hline $\begin{array}{l}\text { Button et al., } \\
\text { (2003) [11] }\end{array}$ & Fair & $\begin{array}{l}\text { - MPD Physiotherapy } \\
\text { (without head tilting) }\end{array}$ & $\begin{array}{l}\text { - FVC and FEV1 at 5-6 years was } \\
\text { lower for standard than MPD } \\
(p<0.05)\end{array}$ & $\begin{array}{l}\text { - MPD was associated with fewer } \\
\text { respiratory complications than } \\
\text { SPD in infants with CF }\end{array}$ \\
\hline $\begin{array}{l}\text { Lima et al., } \\
\text { (2014) [12] }\end{array}$ & G ood & $\begin{array}{l}\text { - NIV on treadmill 6-min } \\
\text { walk }\end{array}$ & $\begin{array}{l}\text { - Treadmill walk with NIV increase } \\
\text { FEV1 }(p=0,036), \mathrm{Vt}(p=0,005) \\
\text { MV }(p=0,013) \text { after test. }\end{array}$ & $\begin{array}{l}\text { - During treadmill walking test, } \\
\text { NIV change lung function in or- } \\
\text { der to optimized ventilation } \\
\text { - NIV is an effective tool to in- } \\
\text { crease functional capacity in chil- } \\
\text { dren with CF. }\end{array}$ \\
\hline $\begin{array}{l}\text { Mcllwaine et al., } \\
\text { (2001) [13] }\end{array}$ & Fair & $\begin{array}{l}\text { - } 1 \text { year physiotherapy } \\
\text { with oscillating PEP us- } \\
\text { ing flutter device }\end{array}$ & $\begin{array}{l}\text { - Flutter group showed greater } \\
\text { mean annual rate of decline in } \\
\text { FVC compared with the PEP } \\
\text { group }(p=0.05) \& \text { in FEV1 } \\
(p=0.08)\end{array}$ & $\begin{array}{l}\text { - Flutter was not as effective in } \\
\text { maintaining pulmonary functions } \\
\text { compared with PEP }\end{array}$ \\
\hline (2010) [14] & Good & $\begin{array}{l}\text { - PD with percussion ver- } \\
\text { sus AD }\end{array}$ & $\begin{array}{l}\text { - Both the AD and PD groups dem- } \\
\text { onstrated improved pulmonary } \\
\text { functions with no significant dif- } \\
\text { ference between the two groups. } \\
\text { - Change in FVC }(p=0.46), \text { FEV1 } \\
(p=0.63), \text { FEF } 25-75 \%(p=0.21)\end{array}$ & $\begin{array}{l}\text { - Both AD and PD are effective } \\
\text { methods of performing physio- } \\
\text { therapy for CF patients } \\
\text { - The benefits of either technique } \\
\text { are enhanced by measures which } \\
\text { encourage adherence }\end{array}$ \\
\hline $\begin{array}{l}\text { Phillips et al., } \\
\text { (2004) [15] }\end{array}$ & Good & $\begin{array}{l}\text { - ACBT versus High- } \\
\text { frequency external chest } \\
\text { compression (HFCC) by } \\
\text { Hayek Cuirass (oscilla- } \\
\text { tion jacket) }\end{array}$ & $\begin{array}{l}\text { - Patients exhibited a marked pref- } \\
\text { erence for AD technique. } \\
\text { - Pulmonary functions improved } \\
\text { significantly after morning } \\
\text { ACBT: FVC }(p<0.03) \text {; FEV1 }\end{array}$ & $\begin{array}{l}\text { - Compared with ACBT, HFCC by } \\
\text { Hayek Cuirass is not an effective } \\
\text { airway clearance treatment mo- } \\
\text { dality for children with CF during } \\
\text { an infective exacerbation }\end{array}$ \\
\hline
\end{tabular}
$(p<0.03)$ and following afterno0n ACBT, FVC $(p<0.02)$, no significant cha-nge in FEV1.

- Pulmonary functions did not change at any time following HFCC.

\begin{tabular}{|c|c|c|}
\hline $\begin{array}{l}\text { Tannenbaum et } \\
\text { al., (2007) [16] }\end{array}$ & Good & $\begin{array}{l}\text { - CPT under anesthesia } \\
\text { (before the surgical pro- } \\
\text { cedure) }\end{array}$ \\
\hline $\begin{array}{l}\text { Williams et al., } \\
\text { (2001) [17] }\end{array}$ & Fair & $\begin{array}{l}\text { - Therapist-assisted ACBT } \\
\text { versus independent } \\
\text { ACBT }\end{array}$ \\
\hline
\end{tabular}

- Both groups showed a nonsignificant decline in FEV1 the day after surgery.

- No significant within- or betweengroup differences in tidal volume following treatment in both groups

- Significant improvements in pulmonary functions 24 hours following therapist-assisted ACBT

- Carry-over effect following therapist-assisted ACBT: Observed reduction in airways obstruction.

\begin{abstract}
- The unanticipated decline in respiratory functions immediately following physiotherapy was short-lived and not discernible in longer term measure of FEV1 post-operatively
\end{abstract}

- When therapist-assisted ACBT was conducted in Day1, improvements were observed for a number of pulmonary functions parameters on the second day of testing.

\begin{tabular}{ll}
\hline ACBT & : Active cycle of breathing. \\
AD & : Autogenic drainage. CF: Cystic fibrosis. \\
Crs & : Respiratory system compliance. \\
FEV1 & : Forced expiratory volume in one second. \\
FVC & : Forced vital capacity. \\
HFCC & : High-frequency chest compressions. \\
MEF75/25 & : Mean expiratory flow at $75-25 \%$ of FVC.
\end{tabular}

MPT : Modified physiotherapy.

MV : Minute volume.

NIV : Noninvasive ventilation.

PD : Postural drainage.

PEP : Positive expiratory pressure.

PIP : Peak inspiratory pressure.
Rrs : Respiratory system resistance.

SPT : Standard physiotherapy.

TWT : Treadmill walking test.

$\mathrm{Vab}$ : Abdominal volume.

Vt : Tidal volume.

Vrcp : Pulmonary rib cage volume.

MPD : Modified Postural Drainage.

SPD : Standard Postural Drainage. 


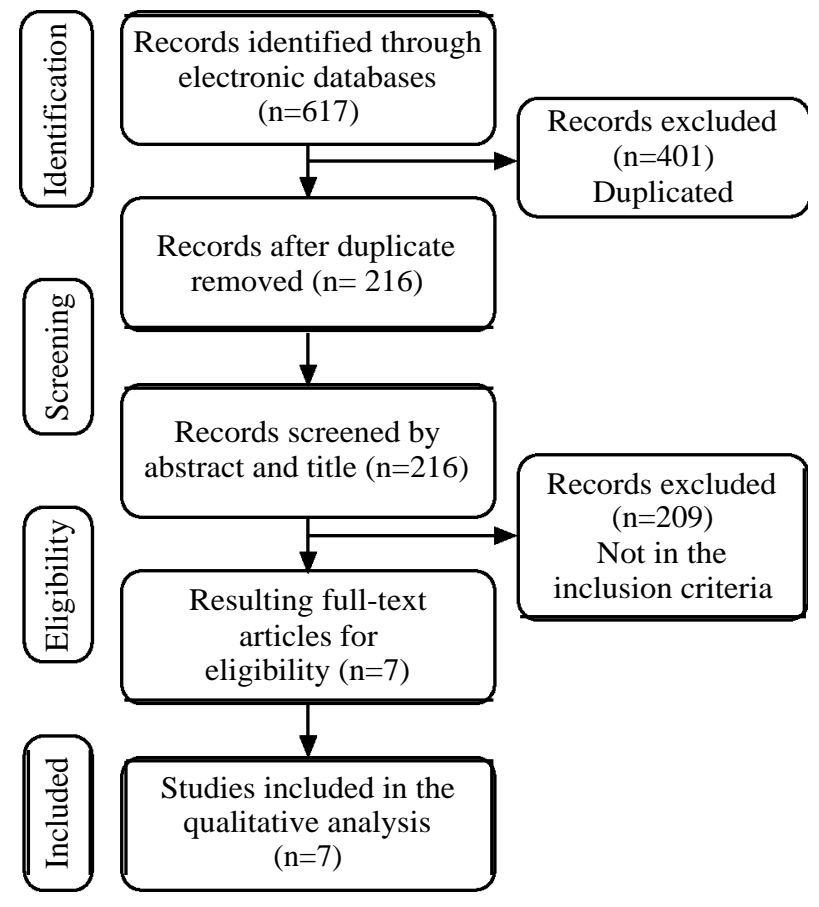

Fig. (1): The PRISMA flow chart of the included studies in the review.

\section{Discussion}

This study systematically reviewed the available published RCTs on different CPT interventions used to improve pulmonary functions in children with $\mathrm{CF}$; it revealed moderate evidence about the effectiveness of PD, autogenic drainage, noninvasive ventilation and independent ACBT technique; limited evidence for the effectiveness of modified PD,PEP and therapist-assisted ACBT. Moderate evidence was found that Hayek oscillator or CPT during anaesthesia preoperatively is ineffective in improving pulmonary functions in children with $\mathrm{CF}$.

Seven RCTs that met the eligibility criteria and were included in the current review; they studied various CPT interventions. Explanations were reported about the possible interventions improving pulmonary functions in children with $\mathrm{CF}$; it was stated that standard CPT plays an integral role in the respiratory management of children with $\mathrm{CF}$ by enhancing the clearance of broncho-pulmonary secretions clearance and pulmonary functions [18-20].

Postural drainage is one of the CPT modalities; mostly used in infants with $\mathrm{CF}$ from diagnosis up to maturity, the modified PD is recommended for airway clearance in children with CF under two years of age [21]. Recent Cochrane review [22] compared the effects of standard PD $\left(15^{\circ}\right.$ to $45^{\circ}$ head-down tilt $)$ with modified PD $\left(15^{\circ}\right.$ to $30^{\circ}$ headup tilt) with regard to gastroesophageal reflux in infants and young children with $\mathrm{CF}$; its analysis revealed that modified $\mathrm{PD}$ is associated with a lower number of gastroesophageal reflux episodes and fewer respiratory complications on a longterm basis. In the current review, analysis revealed moderate evidence regarding the use of PD to improve pulmonary functions in children with $\mathrm{CF}$.

Autogenic Drainage is another airway clearance technique that is unlike PD, individually adjusted and controlled; does not need the use of special equipment; has not been associated with hypoxemia or aspiration. It was suggested that both traditional $\mathrm{PD}$ and $\mathrm{AD}$ can be effective CPT techniques for patients with $\mathrm{CF}$ [14].

Noninvasive ventilation has been used to treat acute and chronic pulmonary patients; it was showed to optimize alveolar ventilation, gas exchange, reduce pulmonary hyperinflation and air trapping, in addition to improve walk distance on treadmill. It was reported that NIV is an effective tool to improve functional capacity in children with $\mathrm{CF}$ [12].

Positive expiratory pressure is a device that promotes intrapulmonary distribution of ventilation by alveoli opening; it also provides positive pressure behind the mucus to push it out of the lungs [23]. Flutter is a small device that creates high frequency oscillation as expired air passes through it, it was reported that flutter is not as effective as PEP in maintaining pulmonary functions for patients with $\mathrm{CF}$ [13].

Active cycle of breathing techniques is an airway clearance technique that is used independently or therapist-assisted by the physiotherapist providing manual facilitation during the thoracic expansion exercises and huffing, no significant difference in pulmonary function parameters was reported between the two techniques [17].

High Frequency Chest Compression (HFCC) is not routinely indicated for secretion clearance in children with CF; it was stated that HFCC is not effective as ACBT in airway clearance during infective exacerbation.

The current review highlights the available variety of CPT interventions; but there were few number of RCTs available for each intervention and small number of participants assessed; the clinical heterogeneity regarding interventions used in the included studies limits the degree of com- 
parison between the results of these studies and makes meta-analyses inappropriate.

\section{Conclusion:}

The present evidence supports the use of different CPT interventions for improving pulmonary functions in children with $\mathrm{CF}$.

Although findings of this review support the effectiveness of using CPT interventions for children with CF; additional RCTs with larger sample sizes are still needed to confirm the present evidence. The limited evidence about the effectiveness of modified PD, PEP and therapist-assisted ACBT also needs further well-designed researches.

\section{References}

1- WEILER C.A. and DRUMM M.L.: Genetic influences on cystic fibrosis lung disease severity. Front. Pharmacol., 4 (40), 2013.

2- BRENNAN M.L. and SCHRIJVER I.: A review of Associated Phenotypes, use of molecular diagnostic approaches, genetic characteristics, progress, and dilemm. The Journal of Molecular Diagnostics., 18 (1), 2016.

3- KAREN Z.V. and CLEMENT L.R.: Diagnosis of Cystic Fibrosis. Clinic. Rev. Allerg. Immunol., 35: 100-106, 2008.

4- MCKOY N.A., SALDANHA I.J., ODELOLA O.A., et al.: Active cycle of breathing technique for cystic fibrosis. Cochrane Database of Systematic Reviews. Issue, 12, 2012.

5- VAN DER SCHANS C.P., PRASAD A. and MAIN E.: Chest physiotherapy compared to no chest physiotherapy for cystic fibrosis. Cochrane Database of Systematic Reviews. Issue 2, 2000.

6- MOHER D., LIBERATI A., TETZLAFF J., et al.: Preferred reporting items for systematic reviews and meta-analyses: The PRISMA statement. Annals of Internal Medicine. 151 (4): 264-269, 2009.

7- ELNAHHAS A.M., ELSHENNAWY S. and ALY M.G.: Effects of backward gait training on balance, gross motor function, and gait in children with cerebral palsy: A systematic review. Clinical Rehabilitation, 33 (1), 2019.

8- MAHER C.G., SHERRINGTON C., HERBERT R.D., et al.: Reliability of the PEDro scale for rating quality of randomized controlled trials. Physical Therapy, 83 (8): 713-21, 2003.

9- VALKENET K., VAN DE PORT IGL, DRONKERS J.J., et al.: The effects of preoperative exercise therapy on postoperative outcome: A systematic review. Clin. Rehabil, 25 (2): 99-111, 2011.

10- SACKETT D.L.: Therapy. Evidence based medicine. How to practice and teach EBM, 136-7, 2000.

11-BUTTON B., HEINE R., CATTO-SMITH A., et al.: Chest physiotherapy in infants with cystic fibrosis: To tip or not? A five-year study. Pediatric Pulmonology, 35 (3): 208-2 13, 2003.

12- LIMA C., DE ANDRADE A., CAMPOS S., et al.: Effects of noninvasive ventilation on treadmill 6-min walk distance and regional chest wall volumes in cystic fibrosis: Randomized controlled trial. Respiratory Medicine, 108 (10): 1460-1468, 2014.

13- McILWAINE P., WONG L., PEACOCK D., et al.: Longterm comparative trial of positive expiratory pressure versus oscillating positive expiratory pressure (flutter) physiotherapy in the treatment of cystic fibrosis. The Journal of Pediatrics, 138 (6): 845-850, 2001.

14- McILWAINE M., WONG L., CHILVERS M., et al.: Long-term comparative trial of two different physiotherapy techniques; postural drainage with percussion and autogenic drainage, in the treatment of cystic fibrosis. Pediatric Pulmonology, 45 (11): 1064-1069, 2010.

15- PHILLIPS G., PIKE S., JAFFÉ A., et al.: Comparison of active cycle of breathing and high-frequency oscillation jacket in children with cystic fibrosis. Pediatric Pulmonology, 37 (1): 71-75, 2001.

16- TANNENBAUM E., PRASAD S., DINWIDDIE R., et al.: Chest physiotherapy during anesthesia for children with cystic fibrosis: Effects on respiratory function. Pediatric Pulmonology, 42 (12): 1152-1158, 2007.

17- Williams M.T., Parsons D.W., Frick R.A., et al.: Acute respiratory infection in patients with cystic fibrosis with mild pulmonary impairment: Comparison of two physiotherapy regimens. Australian Journal of Physiotherapy. 47: 227-236, 2001.

18- VALKENET K., VAN DE PORT I.G.L., DRONKERS J.J., et al.: The effects of preoperative exercise therapy on postoperative outcome: A systematic review. Clin. Rehabil., 25 (2): 99-111, 2011.

19- URQUHART D., SELL Z., DHOUIEB E., et al.: Effects of a supervised, outpatient exercise and physiotherapy programme in children with cystic fibrosis. Pediatr. Pulmonol., 47: 1235-1241, 2012

20- SAVI D., SIMMONDS N., DI PAOLO M., et al.: Relationship between pulmonary exacerbations and daily physical activity in adults with cystic fibrosis. BMC Pulm Med., 15: 1-7, 2015.

21- BUTTON B.M., WILSON C., DENTICE R., et al.: Physiotherapy for cystic fibrosis in Australia and New Zealand: A clinical practice guideline. Respirology, 21 (4): 656667,2016

22- FREITAS D.A., CHAVES G.S.S., SANTINO T.A., et al.: Standard (head-down tilt) versus modified (without headdown tilt) postural drainage in infants and young children with cystic fibrosis. Cochrane Database of Systematic Reviews, Issue 3, 2018.

23- McILWAINE M., BUTTON B. and DWAN K.: positive expiratory pressure physiotherapy for airway clearance in people with cystic fibrosis. Cochrane Database of Systematic Reviews, Issue 6, 2015. 


\section{علاج طبيعى للصدر على وظائف التثفس

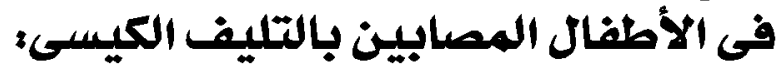

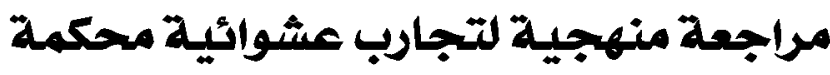

خلفية البحث: إعتلال التفس هو المسبب الرئيسى للإعتلال والوفاة في مرض التيف الكيف الكيسى. الأطفال المصابين بمرض التليف الكيسى عادة يتلقون العلاج الطبيعى للصدر كجزء من علاجهم.

الهدف من البحت: تهدف هذه المراجع المنهجية إلى دراسة تأثير تدخلات العلاج الطبيعى المدر على وظائف التفس عند الأطفال

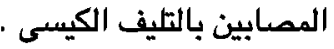

طرق البحث: البحث فى قواعد اليانات (Pubmed و Pedro, Cochrane) وإختيار التجارب العشوائية المحكمة على الأطفال المصابين

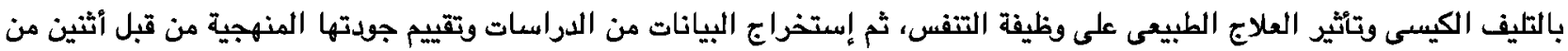
المراجعين المستقلين بإستخدام مقياس قاعدة بيانات الأدلة العلاجية (PEDro) وقد أستخدم مقياس (Sackett) المعدل لتقييم مستوى الأدلة.

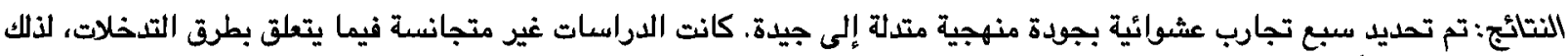

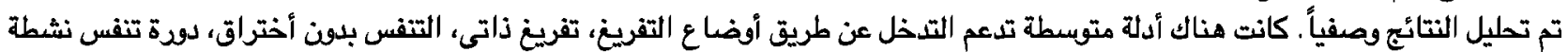

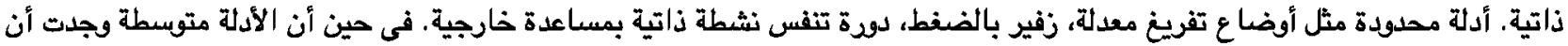

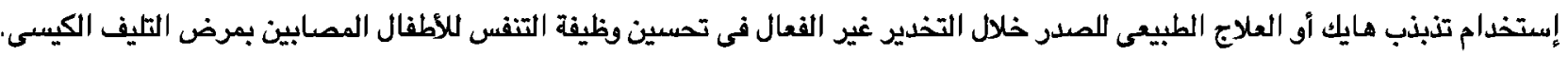
الإستتاج: يدعم الدليل الحالى فعالية تدخل العلاج الطبيعى الصدر لتحسين وظيفة التنفس لدى الأطفال المصابين بالتليف الكيسى. 